\title{
ANTHROPOMETRIC COMPARISON OF ANTHROPOMETRIC TEST DEVICE (ATD) AND NIGERIAN FEMALE ADULT
}

Rafukka, I. A.

Department of Mechanical Engineering, Bayero University, PMB 3011, Kano, Nigeria

*Correspondence author: ibrahimrafukka@yahoo.com , Phone No.: +2348038749657

\section{ABSTRACT}

Anthropometric test device (ATD) is surrogate used in automotive crash testing. Female ATDs used worldwide in the evaluation of vehicle safety performance was produced based on anthropometry of U.S. population. This work is aimed at assessing the difference between the anthropometric dimensions of Nigerian female adults from three major ethnic groups and ATDs, utilizing data reported in the literature. The comparison revealed differences varying from $0.5 \%$ to $2.1 \%$ in stature and $1.5 \%$ to $16.7 \%$ in the body weight. Small female and mid size female ATD could represent Igbo female because the difference in both stature and weight is within 2\%. It was also found that female ATDs could not represent Hausa and Yoruba female population. ATD stature and weight targets differ from the Nigerian female population by less than 11 percentile points. This will lead to different injury outcomes in vehicular crashes. Vehicles certified using the ATD might not be safer for Nigerian female occupant. Therefore, car designers and manufactures need to consider the anthropometric differences in their future designs to ensure that vehicle used by Nigerians are evaluated using ATDs that truly represent the population.

Keywords: Anthropometry; ATD; Crash test; Vehicle safety

\section{INTRODUCTION}

Anthropometric test devices have been the tools employed in crash testing of vehicle to evaluate occupant injury severities for various crash configurations. They are designed to represent human dimensions, shape, weight and articulation of joints. Dummies are instrumented to measure the accelerations, moments and forces experienced by head, neck, chest and femur during crash. Biomechanical responses of the dummy are compared with standards to ensure that vehicle is safe for the occupants. The most commonly used ATDs are Hybrid III family which include Hybrid III $5^{\text {th }}$ percentile female shown in Figure 1. It is intended to be representative of typical U.S. $5^{\text {th }}$ percentile female in stature, weight and shape (Reed and Rupp 2013).

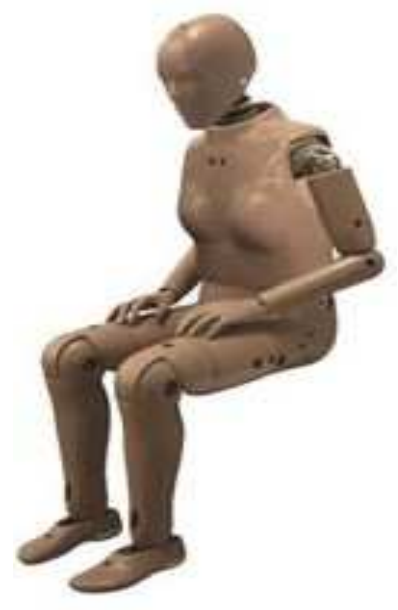

Figure 1 Hybrid III $5^{\text {th }}$ Percentile Female ATD (Humanetics 2017)

Various safety standards have been established around the world with aim of ensuring safety for the vehicle occupants. New cars produced most undergo crash test to satisfy certain safety requirements for the occupant at various impact conditions.

New Car Assessment Programme (NCAP) requires vehicle to pass certain safety requirements in frontal, offset and side impacts. Injury threshold values for various human body regions were set for given impact condition. Some countries such as China and Korea have established NCAP that suit their safety requirements. Vehicle crash testing with Hybrid III $5^{\text {th }}$ percentile female is currently a requirement of Euro NCAP, US NCAP, China NCAP and Korea NCAP (Isa et al., 2016). 
This implies that there is concern about injuries sustained by small female in vehicle crashes. There are recently efforts by automobile stakeholders and Nigerian government of producing made in Nigerian vehicles. Some companies have started assembling cars sold in Nigeria. To provide effective protection in car crashes, Nigerian female adults' anthropometry must be taken in to consideration in evaluating safety performance of vehicles used by Nigerian occupants. Nigeria depends on imported used and new vehicles that are produced based on safety standards of developed world. Safety performance of these vehicles is evaluated using ATDs representing mainly U.S. population (Cao et al., 2015). These ATDs might provide injury parameters such as head injury criteria and chest acceleration that are different from that of Nigerian vehicle occupants because of differences in anthropometric characteristics. There have been many studies recently on comparing various populations of the world and ATDs in order to determine the validity of using the ATDs in crash test. Reed and Rupp (2013) compare current U.S. adults' anthropometry with Hybrid III dummy dimensions. It was found that small and midsize female ATD could not represent current U.S. population. Isa et al., (2016) studied the difference in anthropometry between ATD and Malaysian adults. It was concluded that current ATDs do not represent Malaysian small female adult. Chinese female adults were found to be different from ATDs in terms of stature and body weight (Cao et al., 2015). For child vehicle occupants however, Serre et al., (2006) revealed that, French 3 and 6 year old child anthropometry differ from crash dummies for various dimensions. A significant difference in anthropometric dimensions between three year old Nigerian child and ATDs were also determined by Rafukka et al., (2016). There is no study on assessment of differences between Nigerian female adult and ATDs despite the fact that Nigeria is one of the major vehicle users in Africa. This work is aimed at assessing the difference in anthropometry between Nigerian female adult and ATDs in order to determine the validity of using the dummies in crash testing of vehicles used by Nigerians.

\section{MATERIALS AND METHODS}

\section{Data Source}

The data used in this study was obtained from previous studies in which stature and body weight of three major ethnic groups in Nigeria was published. This is done in order to ensure that every part of the country is represented. Studies on anthropometric comparison between ATDs and female adults for Malaysia, U.S. and China were carried out using data from national anthropometric database (Reed and Rupp 2013; Cao et al., 2015; Isa et al., 2016). However, there is still no anthropometric database for Nigerian population (Onawumi and Lucas 2012; Samuel et al., 2016). Studies for anthropometric data of Nigerian adults especially for weight and stature were for medical research involving blood pressure (Anyanwu et al., 2010; Chinedu and Emiloju 2014; Chukwujekwu et al., 2014; Okamkpa et al., 2016). Some research are for ergonomic applications for school furniture and vehicle seat (Onawumi and Lucas 2012; Ismaila et al., 2013; Samuel et al., 2016). Other works deal with studying the anthropometric characteristics of various ethnic groups (Oladipo et al., 2005; Goon et al., 2011; Taura 2012; Egbe et al., 2014; Ogunlade and Adalumo 2015; Alabi et al., 2017). One study that is recent and has high number of subjects was selected for each of the three major ethnic groups of Hausa, Igbo and Yoruba. Another study by Alabi et al., (2017) further confirmed the stature of female adults from three ethnic groups. The difference in stature from Alabi et al., (2017) and the one from the three selected studies was found to be within $1.2 \%$. All the three studies show a significant difference in mean between male and female subjects in both stature and weight (P-value $\leq 0.05)$. This study is limited to weight and stature because the two parameters are the reference dimensions that significantly affects the biomechanical response of the ATDs. Other dimensions of ATD are derived from individual that has similar size with the reference dimensions. Number of samples from the three studies were in accordance with recommendation of WHO which requires anthropometric studies to have at least 200 samples (Bridger 2003). Table 1 shows stature and body weight of Nigerian female adults from the three selected studies. The data was obtained in terms of mean and standard deviation.

Table 1 Anthropometric data of Nigerian female adults

\begin{tabular}{|c|c|c|c|c|c|}
\hline Source & Anthropometry & Age & No. of Subject & Mean & $\begin{array}{l}\text { Standard } \\
\text { deviation }\end{array}$ \\
\hline \multirow{2}{*}{$\begin{array}{l}\text { (Taura 2012) } \\
\text { (Hausa) }\end{array}$} & Stature $(\mathrm{mm})$ & $18-60$ & 504 & 1600 & \pm 68 \\
\hline & Weight $(\mathrm{kg})$ & $18-60$ & 504 & 59.1 & \pm 12.3 \\
\hline \multirow{2}{*}{$\begin{array}{l}\text { (Okamkpa et al., } \\
2016) \\
\text { (Igbo) }\end{array}$} & Stature $(\mathrm{mm})$ & $28-74$ & 282 & 1602.9 & \pm 74.3 \\
\hline & Weight (kg) & $28-74$ & 282 & 63.3 & \pm 9.7 \\
\hline \multirow{2}{*}{$\begin{array}{l}\text { (Ogunlade and } \\
\text { Adalumo 2015) } \\
\text { (Yoruba) }\end{array}$} & Stature $(\mathrm{mm})$ & $18-41$ & 242 & 1620 & \pm 70 \\
\hline & Weight $(\mathrm{kg})$ & $18-41$ & 242 & 58.5 & \pm 9.5 \\
\hline
\end{tabular}


The weight and stature of small female ATDs were obtained from (Mertz et al., 2001). Because the midsize female ATD is not yet available, Nigerian midsize female anthropometry was compared with $50^{\text {th }}$ percentile U.S. female from Schneider et al., (1983) who derives data of U.S. people from sources similar to those used for Hybrid III dummy.

\section{Data Analysis}

Various percentiles can be computed using mean and standard deviation because linear dimensions of the human body are normally distributed (Pheasant and Haslegrave 2016). Though body weight shows modest skew distribution in some populations, the errors of approximating it to normal distribution are considered negligible (Pheasant and Haslegrave 2016). Thus, assuming normal distribution, the $5^{\text {th }}$ and $50^{\text {th }}$ percentiles were calculated using the equation:

$X=\mu+Z \sigma$

Where $\mu$ is the mean, $Z$ is the value from standard normal distribution and $\sigma$ is the standard deviation. Small $\left(5^{\text {th }}\right)$ and mid size $\left(50^{\text {th }}\right)$ female percentiles for each of the three ethnic groups was computed using equation (i) by substituting the values of mean and standard deviation from Table $1 . Z$ values of the $5^{\text {th }}$ and $95^{\text {th }}$ percentiles were obtained from the standard normal distribution table.

The percentage difference between Nigerian female adults and ATDs was calculated as follows:

Percentage difference (\% diff.)

$$
=\frac{\text { Nigerian female adult data }- \text { ATD data }}{\text { ATD data }}
$$

(ii)

\section{RESULTS}

The anthropometric differences between small and mid size Nigerian female and corresponding ATDs are as presented in Table 2. Negative value indicates that Nigerian female dimensions are lower than reference ATDs.

Table 2 Anthropometric differences between Nigerian female adult and ATD

\begin{tabular}{|c|c|c|c|c|c|c|}
\hline Variables & $\begin{array}{l}\text { Small } \\
\text { female } \\
\text { ATD }\end{array}$ & $\begin{array}{l}\text { Small } \\
\text { female } \\
\text { (Hausa) }\end{array}$ & $\begin{array}{l}\text { \%diff. } \\
(\%)\end{array}$ & $\begin{array}{l}\text { Midsize } \\
\text {-female } \\
\text { ATD }\end{array}$ & $\begin{array}{l}\text { Mid size } \\
\text { female } \\
\text { (Hausa) }\end{array}$ & $\begin{array}{l}\text { \%diff. } \\
(\%)\end{array}$ \\
\hline Stature $(\mathrm{mm})$ & 1513.0 & 1488.1 & -1.6 & 1618.0 & 1600.0 & -1.1 \\
\hline \multirow[t]{3}{*}{ Weight (kg) } & 46.7 & 38.9 & -16.7 & 62.3 & 59.1 & -5.1 \\
\hline & $\begin{array}{l}\text { Small } \\
\text { Female }\end{array}$ & $\begin{array}{l}\text { Small } \\
\text { female }\end{array}$ & $\begin{array}{l}\text { \%diff. } \\
(\%)\end{array}$ & $\begin{array}{l}\text { Midsize } \\
\text {-female }\end{array}$ & $\begin{array}{l}\text { Mid size } \\
\text { female }\end{array}$ & $\begin{array}{l}\text { \%diff. } \\
(\%)\end{array}$ \\
\hline & ATD & (Igbo) & & ATD & (Igbo) & \\
\hline Stature $(\mathrm{mm})$ & 1513.0 & 1480.7 & -2.1 & 1618.0 & 1602.9 & -0.9 \\
\hline \multirow[t]{2}{*}{ Weight $(\mathrm{kg})$} & 46.7 & 47.4 & 1.5 & 62.3 & 63.3 & 1.6 \\
\hline & $\begin{array}{l}\text { Small } \\
\text { Female } \\
\text { ATD }\end{array}$ & $\begin{array}{l}\text { Small } \\
\text { female } \\
\text { (Yoruba) }\end{array}$ & $\begin{array}{l}\text { \%diff. } \\
(\%)\end{array}$ & $\begin{array}{l}\text { Midsize } \\
\text {-female } \\
\text { ATD }\end{array}$ & $\begin{array}{l}\text { Mid size } \\
\text { female } \\
\text { (Yoruba) }\end{array}$ & $\begin{array}{l}\text { \%diff. } \\
(\%)\end{array}$ \\
\hline Stature $(\mathrm{mm})$ & 1513.0 & 1504.9 & -0.5 & 1618.0 & 1620.0 & 0.1 \\
\hline Weight (kg) & 46.7 & 42.9 & -8.1 & 62.3 & 58.5 & -6.2 \\
\hline
\end{tabular}

It can be seen from Table 2 that female ATDs are different from Nigerian female adults in both stature and body weight. The difference was large in body weight rather than stature. Small and mid size female from Hausa, Igbo and Yoruba are slightly different from ATDs in stature. Biggest difference of $16.7 \%$ is observed for Hausa female adults in body weight. Yoruba female are approximately equal to small and mid size female ADTs in stature, but the difference in body weight is however very high. Among the three ethnic groups, Igbo female was found to slightly differ from ATDs in both stature and weight with difference ranging from -2.1 to $1.6 \%$. Hence small and mid size female ATD could represent Igbo female in vehicle crash testing because of small difference in anthropometric characteristics.

Table 3 compares percentiles points of female ATDs with their corresponding values in Nigerian female adults. The $5^{\text {th }}$ nominal percentiles of small female ATD correspond to $10^{\text {th }}$ and $11^{\text {th }}$ percentiles of Hausa and Igbo small female respectively. However, small and midsize female Igbo are 1 and 4 percentile points lower than ATDs in body weight. Yoruba midsize female is 1 percentile point below the reference ATD in stature. 
Bajopas Volume 10 Number 2 December, 2017

Table 3 Comparison of percentiles between ATD and male adults for three ethnic groups

\begin{tabular}{|c|c|c|c|c|c|c|}
\hline \multirow[t]{2}{*}{ ATD } & \multicolumn{3}{|l|}{ Stature } & \multicolumn{3}{|l|}{ Weight } \\
\hline & $\begin{array}{l}\text { Reference } \\
\text { Values } \\
\text { ATD } \\
(\mathbf{m m}) \\
\end{array}$ & $\begin{array}{l}\text { Nominal } \\
\text { percentile } \\
\text { ATD }\end{array}$ & $\begin{array}{l}\text { Corresponding } \\
\text { percentile } \\
\text { (Hausa) }\end{array}$ & $\begin{array}{l}\text { Reference } \\
\text { Values } \\
\text { ATD } \\
\text { (kg) } \\
\end{array}$ & $\begin{array}{l}\text { Nominal } \\
\text { percentile } \\
\text { ATD }\end{array}$ & $\begin{array}{l}\text { Corresponding } \\
\text { percentile } \\
\text { (Hausa) }\end{array}$ \\
\hline $\begin{array}{l}\text { Small } \\
\text { Female }\end{array}$ & 1513.0 & 5 & 10 & 46.7 & 5 & 16 \\
\hline $\begin{array}{l}\text { Mid size } \\
\text { Female }\end{array}$ & 1618.0 & 50 & 60 & 62.3 & 50 & 60 \\
\hline & $\begin{array}{l}\text { Reference } \\
\text { Values } \\
\text { ATD } \\
(\mathbf{m m}) \\
\end{array}$ & $\begin{array}{l}\text { Nominal } \\
\text { percentile } \\
\text { ATD }\end{array}$ & $\begin{array}{l}\text { Corresponding } \\
\text { percentile } \\
\text { (Igbo) }\end{array}$ & $\begin{array}{l}\text { Reference } \\
\text { Values } \\
\text { ATD } \\
\text { (kg) } \\
\end{array}$ & $\begin{array}{l}\text { Nominal } \\
\text { percentile } \\
\text { ATD }\end{array}$ & $\begin{array}{l}\text { Corresponding } \\
\text { percentile } \\
\text { (Igbo) }\end{array}$ \\
\hline $\begin{array}{l}\text { Small } \\
\text { Female }\end{array}$ & 1513.0 & 5 & 11 & 46.7 & 5 & 4 \\
\hline $\begin{array}{l}\text { Mid size } \\
\text { Female }\end{array}$ & 1618.0 & 50 & 58 & 62.3 & 50 & 46 \\
\hline & $\begin{array}{l}\text { Reference } \\
\text { Values } \\
\text { ATD } \\
(\mathbf{m m}) \\
\end{array}$ & $\begin{array}{l}\text { Nominal } \\
\text { percentile } \\
\text { ATD }\end{array}$ & $\begin{array}{l}\text { Corresponding } \\
\text { percentile } \\
\text { (Yoruba) }\end{array}$ & $\begin{array}{l}\text { Reference } \\
\text { Values } \\
\text { ATD } \\
\text { (kg) } \\
\end{array}$ & $\begin{array}{l}\text { Nominal } \\
\text { percentile } \\
\text { ATD }\end{array}$ & $\begin{array}{l}\text { Corresponding } \\
\text { percentile } \\
\text { (Yoruba) }\end{array}$ \\
\hline $\begin{array}{l}\text { Small } \\
\text { Female }\end{array}$ & 1513.0 & 5 & 6 & 46.7 & 5 & 11 \\
\hline $\begin{array}{l}\text { Mid size } \\
\text { Female }\end{array}$ & 1618.0 & 50 & 49 & 62.3 & 50 & 66 \\
\hline
\end{tabular}

\section{DISCUSSION}

The main purpose of this study is to compare the anthropometry of Nigerian female adults and ATDs. The results demonstrate that reference ATDs are different from the female adult of three Nigerian major ethnic groups. Percentage difference between ATD and Nigerian female varying from $0.5 \%$ to $2.1 \%$ is observed in stature as shown in Table 2. Large difference in body weight ranging from $1.5 \%$ to $16.7 \%$ was also found. Small female and mid size female ATD could represent Igbo female because the difference in both stature and weight is within $2 \%$. ATD stature and weight targets differ from the Nigerian female population by less than 11 percentile points. Small ATDs that are used in the evaluation of vehicle safety performance are not truly representing Hausa and Yoruba female adults in both stature and body weight.

Injury parameters could be different for occupant of different sizes hence there is need to take in to account the occupant size in restraint system and vehicle design (Happee et al., 1998). If the size of occupant is different from that of ATDs, the position of head and neck relative to the airbag and restraint system will be different from the one intended in the design. Air bag energy absorption from head and neck depends on the trigger time and position of head relative to air bag (Melvin et al., 1993). Occupants that are smaller than the crash dummies were reported to have higher neck injuries due to closeness of dummy neck with seat belt (Isa et al., 2016). Since Nigerian female adult is smaller than ATD, seat belt routings would be close to their neck than hybrid III dummy which lead to high neck moments and forces. Weight plays an important role in injury severities sustained by the occupant in crash because it is related to the energy absorption of airbag, seat belt and knee bolster. Large differences in weight between ATDs and Nigerian female shown in the aforementioned results (Table 2) indicate that injury mitigation systems may not provide optimum protection to Nigerian female adults. It is therefore important to consider Nigerian population in vehicle designs. New vehicles should be tested using female ATDs of Nigerian anthropometry.

Table 4 presents the difference between small female adults and ATDs for some populations of the world. U.S. female adults are close to ATDs in stature and about $7.7 \%$ higher in body weight, which reflects increase in obesity of U.S. adults. The ATDs were produced based on U.S. anthropometric data collected about three decades ago, as such small female ATD does not represent current U.S. population (Reed and Rupp 2013). Chinese and Malaysian female adults are slightly lower in stature with close values (Cao et al., 2015; Isa et al., 2016). It is clear that there is a mismatch between female ATD and two most populated countries in the world (China and U.S.) especially in the body weight. It is interesting to note that among all the populations compared, Igbo small female was closer to small female ATD in stature and body weight. In summary, current ATDs may not sufficiently represent U.S., Malaysia, China and Nigerian Hausa and Yoruba female. 
Bajopas Volume 10 Number 2 December, 2017

Table 4 Percentage difference between ATDs and adults population for some countries

\begin{tabular}{lll}
\hline Population & $\begin{array}{l}\text { Difference between small size } \\
\text { female and ATD in Stature } \\
(\%)\end{array}$ & $\begin{array}{l}\text { Difference between small size } \\
\text { female and ATD in body weight } \\
(\%)\end{array}$ \\
\hline U.S. (Reed and Rupp 2013) & -0.3 & 7.7 \\
\hline China (Cao et al., 2015) & -1.9 & -10.1 \\
\hline Malaysia (Isa et al., 2016) & -2.2 & -12.2 \\
\hline Nigeria Hausa (current study) & -1.6 & -16.7 \\
\hline Nigeria Igbo (current study) & -2.1 & 1.5 \\
\hline Nigeria Yoruba(current study) & -0.5 & -8.1 \\
\hline
\end{tabular}

Small sample size is used in the current study as compared to studies of China and Malaysia who employed data from their national database which is not currently available in Nigeria. For further improvement on this work it is therefore recommended that a standardized Nigerian anthropometric database be established in the future to enable research on automotive safety to be conducted. Also the effect of anthropometric data on injury outcome during crash should be studied. This work is important considering the new vehicles being assembled and sold in Nigeria. Crash testing using correct ATDs should become a requirement for manufacturers to sell their cars in Nigeria and Africa in general.

\section{CONCLUSION}

This work proved that Nigerian female adults from three major ethnic groups are generally different from ATDs in both stature and weight. The results indicate that current ATDs are not truly representing Nigerian

\section{REFERENCES}

Alabi, A., Oladipo, G.S., Didia, B.C. and Aigbogun, E.O. (2017). Regression Equations for Stature Prediction in Nigerian Hausas, Igbos and Yorubas From Toe Length and Toe-Length Ratios. Anthropology, 05(01), pp.1-5.

Anyanwu, G.E., Ekezie, J., Danborno, B. and Ugochukwu A. I. (2010). Impact of education on obesity and blood pressure in developing countries: A study on the Ibos of Nigeria. North American Journal of Medical Sciences, 2(7), pp.320-4.

Bridger, R..S. (2003). Introduction to ergonomics 2nd edition. London: Taylor \& Francis.

Cao, L., Zhang, K. and Lv, X. (2015). Comparison of Current ATDs with Chinese Adults in Anthropometry. Traffic Injury Prevention, 9588(February), pp.00-00.

Chinedu, S. and Emiloju, O. (2014). Underweight, overweight and obesity amongst young adults in Ota, Nigeria. Journal of Public Health and Epidemiology, 6(7), pp.235-238.

Chukwujekwu, I.E., Ezejindu, D.N. and Nwosu, N. M. (2014). Anthropometric study of weight, height and blood pressure in children from Nnewi north local government of Anambra state, south east Nigeria. International Journal of Scientific and Research Publications, 4(4), pp.1-4.

Egbe, E.O. Asuquo, O. A., Ekwere, E. O., Olufemi, F. and Ohwovoriole, A. E. (2014). Assessment of anthropometric indices among residents of Calabar, South-East Nigeria. Indian journal of female adults and this signifies differences in biomechanical response and injury level in vehicular crashes. Igbo female are very close to ATDs in weight and stature and therefore small female ATD could represent Igbo female populations. Globally however, percentage difference in body weight and stature for Igbo female was closer to ATDs than Hausa, Yoruba as well as U.S., Malaysian and Chinese adults. It is imperative therefore to put consideration into the differences in anthropometry between Nigerian female adult and ATDs in design of new vehicles used in Nigeria in order to provide effective protection against injuries to the occupants.

\section{Conflict of Interest}

The author declares that there is no conflict of interests regarding the publication of this paper.

\section{Acknowledgement}

The author wishes to thank Bayero University, Kano for providing educational resources to conduct this research work.

endocrinology and metabolism, 18(3), pp.38693.

Goon, D., Toriola, A. L., Musa, D. I. and Akusu, S. (2011). The Relationship Between Arm Span and Stature in Nigerian Adults. Kinesiology, 43, pp.38-43.

Happee, R., Haaster, R., Michaelsen, L. and Hoffmann, R. (1998). Optimisation of Vehicle Passive Safety for Occupants With Varying Anthropometry. Methods, (98), pp.1919-1924.

Humanetics, (2017). Hybrid III 50th Male. Retrieved from http://www.humaneticsatd.com/crashtest-dummies/frontal-impact/hiii-50m

Isa, M. H., Deros, B., Jawi, Z. M., Anwar, K. and Kassim, K. A. (2016). An Anthropometric Comparison of Current Anthropometric Test Devices ( ATDs ) WITH Malaysia Adults. Malaysian Journal of Public Health Medicine, Special Vo(1), pp.15-21.

Ismaila, S.O. Musa, A. I., Adejuyigbe, S. B. and Akinyemi, O. D. (2013). Anthropometric Design of Furniture for Use in Tertiary Institutions in Abeokuta, South- Western Nigeria. Engineering Review, 33(3), pp.179-192.

Melvin, J., Horsch, J. D., McCleary, J. D., Wideman, L. C., Jensen, J. L., et al.

(1993). Assessment of airbag deployment loads with the small female hybrid III dummy (No. 933119). SAE Technical Paper. 
Bajopas Volume 10 Number 2 December, 2017

Mertz, H., Jarrett, K., Moss, S., Salloum, M. and Zhao, Y. (2001). The Hybrid-III 10-year-old Dummy. Stapp car crash journal, 45, pp.319-328.

Ogunlade, O. and Adalumo, O.A. (2015). Mean values , normal limits and sex differences of anthropometry of young adults in a University Community in Nigeria. American Journal of Clinical and Experimental Medicine, 3(1), pp.4447.

Okamkpa, C., Nwankwo, M. and Danborno, B. (2016). Predicting high blood pressure among adults in Southeastern Nigeria using anthropometric variables. Journal of Experimental and Clinical Anatomy, 15(2), p.111.

Oladipo, G.S., Coker, T., Anugweje, K.C. and Abidoye, A.O. (2005). Study of Some Anthropometric Parameters of Itsekiri and Okpe Ethnic Groups of Delta State, South-South Nigeria. International Journal of Community Research, pp.77-80.

Onawumi, A.S. and Lucas, E.B. (2012). Ergonomic investigation of occupational drivers and seat design of taxicabs in Nigeria. ARPN Journal of Science and Technology, 2(3), pp.214-220.

Pheasant, S. and Haslegrave, C.M. (2016).
Bodyspace: Anthropometry, ergonomics and the design of work. CRC Press.

Rafukka, I.A., Sahari, B. B., Nuraini, A. A. and Manohar A. (2016). Anthropometric Comparison of Three-Year-Old Nigerian Child and Crash Dummies. Journal of Transportation Technologies, 6(4), pp.192-199.

Reed, M.P. and Rupp, J.D. (2013). An anthropomorphic comparison of current ATDs with the U.S adult population. Traffic injury prevention, 14(7), pp.703-705.

Samuel, O.A., Israel, D., Moses, F. (2016). Anthropometry Survey of Nigerian Occupational Bus Drivers to Facilitate Sustainable Design of Driver' s Workplace. 5(May), pp.176-182.

Schneider, L.W., Robbins, D. H., Pflug, M. A. and Snyder, R. G. (1983). Development of Anthropometrically Based Design Specifications for an Advanced Adult Anthropomorphic Dummy Family, Volume 1 (UMTRI-83-53-1).

Serre, T., Lalys, L., Brunet, C., Bartoli, C., ChristiaLotter, A. and Leonetti, G. (2006). 3 and 6 Years Old Child Anthropometry and Comparison with Crash Dummies. SAE Technical Paper.

Taura, M. (2012). Evaluation of Anthropometric Status of Hausas of Northern Nigeria. Bayero Journal of Pure and Applied Sciences, 4(2), pp.80-82. 